\title{
Застосування NPWT у лікуванні гнійно-некротичного ураження стопи у хворих на цукровий діабет
}

\begin{abstract}
Мета роботи: уточнити показання та ефективність використання NPWT у лікуванні гострого гнійно-некротичного ураження стопи у хворих на цукровий діабет.

Матеріали і методи. NPWT була використана в лікуванні 15 хворих на цукровий діабет, ускладнений гнійно-некротичним ураженням стопи.

Всі хворі страждали на цукровий діабет 2 типу впродовж 8-23 років, медіана 12 років. Контроль глікемії шляхом приймання таблетованих препаратів здійснювали 6 пацієнтів, шляхом ін’єкцій інсуліну - 9.

Для створення вакуум-аспірації використовували апарати фірми Acelity (USA). Аспірацію здійснювали інтервальним методом із використанням тиску розрідження 100-120 мм рт. ст. впродовж 8-10 хвилин та тиску 60-70 мм рт. ст. впродовж 2-3 хвилин. Результати досліджень та їх обговорення. Ми не мали підстав до застосування різних режимів проведення NPWT. Можливо, така потреба виникне з накопиченням більшої кількості спостережень з різними характеристиками стану тканин нижньої кінцівки та загального стану пацієнта.

Тяжкі ускладнення при застосуванні NPWT в інших клініках спостерігали в 6 \% спостережень. Ми не діагностували ускладнень внаслідок такого лікування.

При узагальненому розгляді іншими дослідниками лікування гнійно-некротичного ураження діабетичної стопи з застосуванням NPWT не мало переваг у результатах порівняно з накладанням вологих пов'язок і загальна частота загоєння ран була низькою для обох технологій. Однак наш досвід виокремлює групи хворих, у яких застосування NPWT дало можливість зберегти опороздатну стопу, тоді як використання вологих пов'язок не ефективне або пов’язане з високим ризиком високої ампутації. Накопичення більшої кількості таких спостережень сприятиме точнішому визначенню місця NPWT в лікуванні діабетичної стопи.
\end{abstract}

Ключові слова: діабетична стопа; NPWT.

Постановка проблеми і аналіз останніх досліджень та публікацій. Застосування негативного тиску (NPWT) набуває все більшого поширення в лікуванні хірургічних хворих. Частка хворих, лікованих за цією технологією в клініках Германії впродовж 10 років, з 2005 по 2014 р., зросла 3 0,22 \% до 0,66 \% [1]. 3 приводу діабетичного ураження стопи NPWT використовували в кожного десятого хворого - 10,1 \%.

За даними мета-аналізу [2], використання NPWT у лікуванні діабетичної виразки стопи є допоміжним засобом, що зумовлює зменшення набряку тканин, сприяє утворенню грануляційної тканини, зменшує тривалість лікування і розміри рани. Водночас на тлі застосування NPWT не спостерігали суттєвого зменшення частоти виникнення ускладнень цукрового діабету.

Міжнародна група експертів у рекомендаціях 2020 р. підтвердила доцільність використання NPWT у лікуванні ран після операційного втручання з приводу діабетичної стопи [3].

Водночас при проведенні систематизованого огляду літератури за базами даних British Nursing Index, CINAHL, Cochrane Central та PubMed дослідники [4] встановили розбіжність щодо величин негативного тиску, який використовували окремі хірурги, а також невідповідність багатьох контрольованих досліджень вимогам, визначеним в CONSORT.

Неможливість адекватного зіставлення даних різних дослідників не дає можливість дійти беззаперечного висновку щодо частоти загоєння рани стопи та виконання високої ампутації кінцівки на тлі лікування діабетичної стопи з використанням NPWT [5, 6].

Окрім вказаних обмежень, немає достеменних рекомендацій щодо режимів, тривалості, показань та ефективності використання NPWT в лікуванні гострого гнійно-некротичного ураження стопи у хворих на цукровий діабет.

Мета роботи: уточнити показання та ефективність використання NPWT у лікуванні гострого гнійно-некротичного ураження стопи у хворих на цукровий діабет.

Матеріали і методи. NPWT застосували при лікуванні 15 хворих на цукровий діабет, ускладнений гнійно-некротичним ураженням стопи. Чоловіків було 9, жінок - 6, вік хворих - від 57 до 73 років, медіана - 64 роки.

Усі хворі страждали на цукровий діабет 2 типу впродовж 8-23 років, медіана 12 років. Контроль 
глікемії шляхом приймання таблетованих препаратів здійснювали 6 пацієнтів, шляхом ін'єкцій інсуліну -9 .

Для створення вакуум-аспірації використовували апарати фірми Acelity (USA). Аспірацію здійснювали інтервальним методом із використанням тиску розрідження 100-120 мм рт. ст. впродовж 8-10 хвилин та тиску 60-70 мм рт. ст. впродовж 2-3 хвилин.

Результати досліджень та їх обговорення. У всіх пацієнтів кровопостачання стопи було задовільним, зважаючи на відсутність переміжної кульгавості, звичайне забарвлення шкіри, пальпаторне визначення пульсації щонайменше на одній з артерій стопи та, за даними ультразвукової доплерографії, колатерального кровотоку артеріями гомілки зі звуженням їхнього просвіту на 60-80 \%.

Гнійно-некротичне ураження переднього відділу стопи в 13 спостереженнях проявлялось деструкцією плесно-фалангових суглобів, при цьому два суглоби були уражені у 5, три - у 8, гнійну артроостеопатію гомілковостопного суглоба спостерігали у 2 пацієнтів.

Унаслідок тривалої затримки надходження в стаціонар, зумовленої незначним больовим синдромом та недооцінкою змін стопи власне хворим, у 13 пацієнтів ураження суглобів було ускладнене виникненням поширеної флегмони стопи.

3 метою усунення вогнища інфекції видалення двох пальців стопи з резекцією дистального відділу кісток плесна було здійснене в 4 спостереженнях, трьох пальців - в 3, резекція переднього відділу стопи - в 8, дренування гомілковостопного суглоба в 2.

Показанням до застосування NPWT у 11 пацієнтів (1 група) вважали поширення гнійного запалення, яке в разі прогресування в найближчі дні становило загрозу збереженню опороздатної стопи, у 4 (2 група) - намагання досягти закриття рани з оголеними кістками плесна і млявими грануляціями по ії̈ краях та в дні.

В усіх спостереженнях проведення NPWT супроводжували призначенням системного антибактеріального лікування. В першу добу лікування вибір антибіотика був емпіричним, відповідно до принципів деескалаційного лікування, в подальшому виходили з даних чутливості мікроорганізмів.

Серед пацієнтів 1 групи у 6 (підгрупа 1.1) NPWT застосували в перші три доби після санаційного хірургічного втручання, у 5 (підгрупа 1.2) - через 6-9 днів після первинного втручання на тлі неочищення рани.
До підгрупи 1.1 входили 4 пацієнти з ураженням переднього відділу стопи та 2 пацієнти з ураженням гомілковостопного суглоба. За даними бактеріоскопії гною в препараті виявляли велику кількість грампозитивних коків великого розміру серед лейкоцитів, що заповнювали все поле зору.

Ретроспективно за результатами мікробіологічного дослідження збудниками гнійного запалення встановили St.aureus в 3 спостереженнях, St.aureus в поєднанні з Ent.faecalis в 2, S.pyogenes в 1. Усі збудники були чутливі до антибіотиків цефалоспоринового ряду, фторхінолонів та карбапенемів.

В усіх спостереженнях у підгрупі 1.1 унаслідок застосування NPWT досягнено очищення рани та покриття ії̈ грануляціями впродовж 4-6 днів.

У пацієнтів підгрупи 1.2 первинна санація гнійного вогнища не привела до зупинки прогресування гнійного запалення. Рана не очищалась від фібрину, грануляції були відсутні або мляві, незначно виражені, в 4 спостереженнях спостерігали поширення ділянки ураження з оголенням кінців кісток по рівню їх резекції, в 2 спостереженнях спостерігали сильний біль у рані на тлі тьмяного забарвлення тканин у ній.

При бактеріоскопії в препараті виявляли поєднання грампозитивних коків невеликого розміру та грампозитивно-негативних паличок на тлі лейкоцитів, що заповнювали поле зору, та поодиноких макрофагів.

Ретроспективно збудниками гнійного запалення за даними мікробіологічного дослідження встановлено Ps.aeruginosa в поєднанні з Ent.faecalis в 2 спостереженнях, E.coli в 1, Ent.faecalis в поєднанні з Cl.Perfringens в 2.

Серед підгрупи 1.2 застосування NPWT впродовж 5-6 днів сприяло очищенню рани та іiї подальшому загоєнню в одного пацієнта. У 2 спостереженнях гнійно-некротичні зміни прогресували, що зумовило виконання ампутації нижньої кінцівки на рівні гомілки. Ще у 2 спостереженнях на тлі проведення NPWT спостерігали певне зменшення болю, але повне його усунення не відбулось. Зважаючи на клінічну оцінку рани та виявлення в ній грам-забарвлених паличок, діагностований компартмент-синдром, спричинений клостридіальною рановою інфекцією. Хворим змінили антибактеріальну терапію, призначили коломіцин, що дало можливість досягти очищення та подальшого загоєння рани.

У групі 2 NPWT призначили через 6-9 днів після первинного втручання. Ознак поширення гнійного запалення не спостерігали, однак рана містила незначну кількість фібрину, мляві грануляції, 3 м'яких тканин виступали оголені кінці 


\section{З ДОСВІДУ РОБОТИ}

кісток плесна. За даними бактеріоскопії в рані виявляли грампозитивні невеликі коки, поодинокі грамнегативні палички.

Ретроспективно збудниками гнійного запалення за даними мікробіологічного дослідження встановлено Ps.aeruginosa в поєднанні з Ent.faecalis у 2 спостереженнях, E.coli в поєднанні з Ent.faecalis у 2 спостереженнях.

У всіх пацієнтів 2 групи застосування NPWT сприяло очищенню рани, активізації росту грануляцій та закриття ними оголених частин кісток плесна. В подальшому 2 пацієнтам виконали автодермопластику для закриття рани, у 2 хворих рана загоїлася вторинним натягом.

Під час виконання вакуум-аспірації в жодному зі спостережень кількість аспірату не перевищувала 50 мл за добу. Заміну вакуум-пов’язки в 4 спостереженнях виконували через три доби.

Обговорення. 3 позиції молекулярної взаємодії загоєння рани відбувається як наслідок пошкодження бар’єра шкіри і регулюється факторами росту та цитокінами, що їх виділяють фібробласти, клітини ендотелію, фагоцити, тромбоцити та кератиноцити у відповідь на імунне подразнення [7]. Провідну роль в цьому відіграють епігенетичні чинники: тривала гіперглікемія та наявність некодувальної РНK. Проведення NPWT сприяє зменшенню рівнів чинників запалення, підвищенню активності факторів росту та ангіогенезу в тканинах [8, 9].

Дані інших дослідників свідчать про можливість використання як меншого, так і більшого тиску розрідження.

При оцінці кровотоку в тканинах встановили, що застосування тиску розрідження величиною 80 мм рт. ст. супроводжується таким же ефектом, що і тиску 125 мм рт. ст. [10].

Водночас використання тиску розрідження величиною до 400 мм рт. ст. після некректомії та зашивання “застиглих” ран супроводжувалось скороченням термінів очищення та загоєння рани, зменшенням вартості та підвищенням загальної ефективності лікування порівняно з використанням традиційних величин тиску [11].

Дослідники вказують, що показанням до припинення застосування NPWT є виділення добової кількості ексудату менше 5 мл впродовж трьох діб, тоді як збільшення ексудації до 15 мл за добу або поява нових вогнищ некрозу слугували показанням до повторної некректомії [11].

Ми не мали підстав до застосування різних режимів проведення NPWT. Можливо, така потреба виникне з накопиченням більшої кількості спостережень $з$ різними характеристиками стану тканин нижньої кінцівки та загального стану пацієнта.

Тяжкі ускладнення при застосуванні NPWT в інших клініках спостерігали в 6 \% спостережень [5]. Ми не діагностували ускладнень внаслідок такого лікування.

Незалежність частоти виникнення ускладнень від способу проведення NPWT [12] свідчить про необхідність корекції причин виникнення гнійно-некротичного ураження одночасно з лікуванням рани. Виконання цієї умови потребує глибокої оцінки перебігу захворювання на цукровий діабет, зумовлених ним та супутніх уражень, а також можливостей впливу на них.

При узагальненому розгляді іншими дослідниками лікування гнійно-некротичного ураження діабетичної стопи з застосуванням NPWT не мало переваг у результатах порівняно з накладанням вологих пов’язок і загальна частота загоєння ран була низькою для обох технологій [13]. Однак наш досвід виокремлює групи хворих, у яких застосування NPWT дало можливість зберегти опороздатну стопу, тоді як використання вологих пов’язок не ефективне або пов'язане з високим ризиком втрати стопи. Накопичення більшої кількості таких спостережень сприятиме точнішому визначенню місця NPWT у лікуванні діабетичної стопи.

Висновки. 1. При ураженні Шарко внаслідок цукрового діабету застосування NPWT на тлі антибактеріальної терапії та іммобілізації зумовлює зупинку деструкції суглоба, що покращує функціональний результат лікування.

2. Застосування NPWT дає можливість отримати ріст грануляцій на оголених кістках та зберегти опороздатну куксу стопи на тлі її субкомпенсованого кровопостачання.

3. На тлі застосування NPWT неповне усунення болю $є$ ознакою компартмент-синдрому внаслідок бактеріальної інфекції і потребує додатково проведення відповідного антибактеріального лікування, тоді як посилення болю свідчить про критичну ішемію стопи. 


\section{З ДОСВІДУ РОБОТИ}

\section{СПИСОК ЛІТЕРАТУРИ}

1. Initiative Chronische Wunden (ICW) e.V. Ten-year analyses of the German DRG data about negative pressure wound therapy / O. von Beckerath, A. Zapenko, J. Dissemond, K. Kröger // Int. Wound J. - 2017. - Vol. 14 (3). - P. 501-507. DOI: 10.1111/ iwj.12635. Epub 2016 Jul 4.

2. Comparison of vacuum sealing drainage and traditional therapy for treatment of diabetic foot ulcers: A meta-analysis / Q. Huang, J.-T. Wang, H.-C. Gu [et al.] // J. Foot Ankle Surg. 2019. Vol. 58(5). - P. 954-958. DOI: 10.1053/j.jfas.2018.12.020. 3. International Working Group on the Diabetic Foot (IWGDF) Guidelines on use of interventions to enhance healing of chronic foot ulcers in diabetes (IWGDF 2019 update) / G. Rayman, P. Vas, K. Dhatariya [et. al] // Diabetes Metab. Res. Rev. - 2020. - Vol. 36, Suppl 1. - P. e3283. DOI: 10.1002/dmrr.3283. 4. Wynn M. The efficacy of negative pressure wound therapy for diabetic foot ulcers: A systematised review / M. Wynn, S. Freeman // J. Tissue Viability. - 2019. Vol. 28 (3). - P. 152160. DOI: 10.1016/j.jtv.2019.04.001. Epub 2019 Apr 10.

5. NPWT in diabetic foot wounds-a systematic review and meta-analysis of observational studies / P. Rys, S. Borys, J. Hohendorff [et. al] // Endocrine. - 2020. Vol. 68 (1). - P. 4455. DOI: 10.1007/s12020-019-02164-9. Epub 2020 Jan 9.

6 . Negative pressure wound therapy for treating foot wounds in people with diabetes mellitus / Z. Liu, J. C. Dumville, R. J. Hinchliffe [et. al] // Meta-Analysis Cochrane Database Syst. Rev. - 2018. Vol. 17; 10 (10):CD010318. DOI:10.1002/14651858.CD010318. pub3.

7. Genetic and molecular basis of diabetic foot ulcers/

S. Jhamb, V. N. Vangaveti, U. H. Malabu // Clinical Review J. Tissue Viability. - 2016. - Vol. 25 (4). P. 229-236. DOI:

\section{REFERENCES}

1. Beckerath, O. von, Zapenko, A., Dissemond, J., \& Kröger, K. (2017). Initiative Chronische Wunden (ICW) e.V. Ten-year analyses of the German DRG data about negative pressure wound therapy. Int. Wound J. 14 (3), 501-507. DOI: 10.1111/ iwj.12635. Epub 2016 Jul 4.

2. Huang, Q., Wang, J.-T., Gu, H.-C., Cao, G., \& Cao J.-C. (2019). Comparison of vacuum sealing drainage and traditional therapy for treatment of diabetic foot ulcers: a meta-analysis. J. Foot Ankle Surg., 58 (5), 954-958. DOI: 10.1053/j.jfas.2018.12.020.

3. Rayman, G., Vas, P., Dhatariya, K., Driver, V., Hartemann, A., Londahl, M., Piaggesi, A., Apelqvist, J., Attinger, C., \& Game, F. (2020). International Working Group on the Diabetic Foot (IWGDF) Guidelines on use of interventions to enhance healing of chronic foot ulcers in diabetes (IWGDF 2019 update) Diabetes Metab. Res. Rev., 36, Suppl, 1, e3283. DOI: 10.1002/dmrr.3283. 4. Wynn, M., \& Freeman, S. (2019). The efficacy of negative pressure wound therapy for diabetic foot ulcers: A systematised review. J. Tissue Viability, 28 (3), 152-160. DOI: 10.1016/j. jtv.2019.04.001. Epub 2019 Apr 10.

5. Rys, P., Borys, S., Hohendorff, J., Zapala, A., Witek, P., Monica, M., Frankfurter, C., Ludwig-Slomczynska, A., KiecWilk, B., \& Malecki M.T. (2020). NPWT in diabetic foot wounds-a systematic review and meta-analysis of observational studies. Endocrine, 68 (1), 44-55. DOI: 10.1007/s12020-01902164-9. Epub 2020 Jan 9.

6. Liu, Z., Dumville, J. C., Hinchliffe, R. J., Cullum, N., Game, F., Stubbs, N., Sweeting, M., \& Peinemann F. (2018). Negative pressure wound therapy for treating foot wounds in people with diabe- 10.1016/j.jtv.2016.06.005. Epub 2016 Jun 25.

8. Effect of negative pressure wound therapy on molecular markers in diabetic foot ulcers / R. A. Karam, N. A. Rezk, T. M. A. Rahman, M. Al Saeed // Gene. - 2018. - Vol. 667. - P. 5661. DOI: 10.1016/j.gene.2018.05.032. Epub 2018 May 11.

9. MicroRNA-126: a promising biomarker for angiogenesis of diabetic wounds treated with negative pressure wound therapy / D. Zhang, Z. Li, Z. Wang [et al.] // Diabetes Metab. Syndr. Obes. - 2019. - Vol. 3 (12). - P. 1685-1696.

DOI: 10.2147/DMSO.S199705. eCollection 2019.

10 . Wound edge microvascular blood flow during negative-pressure wound therapy: examining the effects of pressures from -10 to $-175 \mathrm{mmHg} / \mathrm{O}$. Borgquist, R. Ingemansson, M. Malmsjö // Plast. Reconstr. Surg. - 2010. - Vol. 125 (2). - 502509. DOI: 10.1097/PRS.0b013e3181c82e1f.

11. A modified negative pressure wound therapy for the treatment of refractory wounds / D. Xing, Z. Yang, C. Cao [et al.] // A Preliminary Study. - 2020. - Vol. 99 (28). - P. e21148. Published online 2020 Jul 10. DOI: 10.1097/MD.0000000000021148 PMCID: PMC7360312 PMID: 32664147

12. Evaluation of negative-pressure wound therapy for patients with diabetic foot ulcers: systematic review and meta-analysis / S. Liu, C.-Z. He, Y.-T. Cai [et al.] // Clin. Risk Manag. - 2017. - Vol. 18 (13). - P. 533-544. DOI: 10.2147/TCRM.S131193. eCollection 2017.

13. Negative pressure wound therapy compared with standard moist wound care on diabetic foot ulcers in real-life clinical practice: results of the German DiaFu-RCT Randomized Controlled Trial / D. Seidel, M. Storck, H. Lawall [et al.] // BMJ Open. - 2020. - Vol.10 (3):e026345. DOI: 10.1136/bmjopen-2018-026345.

tes mellitus. Meta-Analysis Cochrane Database Syst. Rev., 17; 10 (10). CD010318. doi:10.1002/14651858.CD010318.pub3.

7. Jhamb, S., Vangaveti, V.N., \& Malabu, U.H. (2016). Genetic and molecular basis of diabetic foot ulcers: Clinical Review J. Tissue Viability, 25 (4), 229-236. DOI: 10.1016/j. jtv.2016.06.005. Epub 2016 Jun 25.

8. Karam, R.A., Rezk, N.A., Rahman, T.M.A., \& Al Saeed, M. (2018). Effect of negative pressure wound therapy on molecular markers in diabetic foot ulcers Gene, 667, 56-61. DOI: 10.1016/j. gene.2018.05.032. Epub 2018 May 11.

9. Zhang, D., Li, Z., Wang, Z., Zeng, F., Xiao, \& Yu, W.A. (2019). MicroRNA-126: a promising biomarker for angiogenesis of diabetic wounds treated with negative pressure wound therapy. Diabetes Metab. Syndr. Obes., 12, 1685-1696. DOI: 10.2147/ DMSO.S199705. eCollection 2019.

10. Borgquist, O., Ingemansson, R., \& Malmsjö, M. (2010). Wound edge microvascular blood flow during negative-pressure wound therapy: examining the effects of pressures from -10 to -175 mmHg. Plast. Reconstr. Surg., 125 (2), 502-509. DOI: 10.1097/PRS.0b013e3181c82e1f.

11. Xing, D., Yang, Z., Cao, C., Dong, Z., Wei, J., Zheng, X., \& Li, W. (2020). A modified negative pressure wound therapy for the treatment of refractory wounds. A Preliminary Study Medicine (Baltimore), 99 (28), e21148. Published online 2020 Jul 10. doi: 10.1097/MD.0000000000021148 PMCID: PMC7360312 PMID: 32664147

12. Liu, S., He, C.-Z., Cai, Y.-T., Xing, Q.-P., Guo, Y.-Z., Chen, Z.-L., Su, J.-L., \& Yang, L.-P. (2017). Evaluation of negative- 
pressure wound therapy for patients with diabetic foot ulcers: systematic review and meta-analysis. Ther. Clin. Risk Manag., 13, 533-544. DOI: 10.2147/TCRM.S131193. eCollection 2017.

13. Seidel, D., Storck, M., Lawall, H., Wozniak, G., Mauckner, P., Hochlenert, D., Wetzel-Roth, W., Sondern, K., Hahn, M., Rothenaicher, G., Krönert, Th., Zink, K., Neugebauer, E.
(2020). Negative pressure wound therapy compared with standard moist wound care on diabetic foot ulcers in real-life clinical practice: results of the German DiaFu-RCT Randomized Controlled Trial. BMJ Open, 10 (3), e026345. DOI: 10.1136/bmjopen-2018-026345.

Kyiv City Hospital No. 1

\section{NPWT USAGE IN DIABETIC FOOT NECROTIC-PURULENT LESION TREATMENT}

The aim of the work: to specify indications and effectiveness of NPWT in treating diabetic patients with necrotic-purulent foot lesion. Materials and Methods. NPWT was applied to treat a necrotic-purulent diabetic foot lesion of 15 patients. All of them had diabetes type 2 for 8-23 years long, median 12 years. Glycemia control with pills used 6 patients, by insulin injection - 9 .

For NPWT Acelity (USA) utensil was used. Aspiration was conducted with 100-120 mm Hg pressure during 8-10 minutes alternating with 60-70 mm Hg pressure during 2-3 minutes.

Results and Discussion. We have no reason for looking for another mode of NPWT. Maybe such reason will appear with the greater amount of cases with different leg and patient characteristics.

There was a serious adverse event in $6 \%$ of cases of NPWT observed by other physicians. We did not have any serious complication. Just by the controlled blinded clinical study NPWT was not superior to standard moist wound care in the diabetic foot cases primarily in the rate of wound closure. Nevertheless, our experience to find out patients for whom NPWT was critical in foot saving while moist wound care was ineffective and with a high risk of high amputation. The accumulation of more such observations will help to more accurately determine the place of NPWT in the treatment of diabetic foot.

Key words: diabetic foot; NPWT.

С. Е. ПОДПРЯТОВ, А. А. ШТАЕР, С. Е. БОНДАР, В. В. ЛИСОВЕЦ, Е. В. ЛЕВИЦКАЯ, С. С. ПОДПРЯТОВ, И. В. САЦЮК, С. М. КОРБУТ

КНП Киевская городская клиническая больница № 1

\section{ПРИМЕНЕНИЕ NРWТ В ЛЕЧЕНИИ ГНОЙНО-НЕКРОТИЧЕСКОГО ПОРАЖЕНИЯ СТОПЫ У БОЛЬНЫХ С САХАРНЫМ ДИАБЕТОМ}

Цель работы: уточнить показания и эффективность использования NPWT в лечении острого гнойно-некротического поражения стопы у больных с сахарным диабетом.

Материалы и методы. NPWT была использована в лечении 15 больных с сахарным диабетом, осложненным гнойно-некротическим поражением стопы.

У всех больных сахарный диабет был в течение 8-23 лет, медиана 12 лет. Контроль гликемии приемом таблетированных препаратов осуществляли 6 пациентов, инъекциями инсулина - 9 .

Для вакуум-аспирации использовали аппараты фирмы Acelity (USA). Аспирацию осуществляли интервальным методом, чередуя отрицательное давление 100-120 мм рт. ст. в течение 8-10 минут и давление 60-70 мм рт. ст в течение 2-3 минут.

Результаты исследований и их обсуждение. Мы не имели оснований для применения различных режимов проведения NPWT. Возможно, такая необходимость возникнет при наборе большего количества наблюдений с различными характеристиками состояния тканей нижней конечности и общего состояния пациента.

Тяжелые осложнения применения NPWT в других клиниках отмечены в 6 \% наблюдений. Мы не наблюдали тяжелые осложнения применения такого лечения.

При обобщенной оценке другими исследователями лечение гнойно-некротического поражения диабетической стопы с применением NPWT не имело преимуществ перед применением влажных повязок, а общая частота заживления ран была низкой для обоих технологий. Однако наш опрыт выделяет группы больных, у которых применение NPWT позволило сохранить опороспособную культю стопы в ситуациях, когда использование влажных повязок не эффективно и/или связано с высоким риском высокой ампутации.

Накопление большего опыта таких наблюдений будет способствовать более точному определению места NPWT в лечении диабетической стопы.

Ключевые слова: диабетическая стопа; NPWT. 